\title{
Escape Rooms in STEM Teaching and Learning-Prospective Field or Declining Trend? A Literature Review
}

\author{
Chantal Lathwesen and Nadja Belova *(D) \\ Department of Chemistry Education, University of Bremen, 28359 Bremen, Germany; \\ c.lathwesen@uni-bremen.de \\ * Correspondence: n.belova@uni-bremen.de
}

check for updates

Citation: Lathwesen, C.; Belova, N. Escape Rooms in STEM Teaching and Learning-Prospective Field or Declining Trend? A Literature Review. Educ. Sci. 2021, 11, 308. https://doi.org/10.3390/ educsci11060308

Academic Editors: José Carlos Piñero Charlo, María Teresa Costado Dios, Enrique Carmona Medeiro and Fernando Lloret

Received: 28 May 2021

Accepted: 16 June 2021

Published: 21 June 2021

Publisher's Note: MDPI stays neutral with regard to jurisdictional claims in published maps and institutional affiliations.

Copyright: (c) 2021 by the authors. Licensee MDPI, Basel, Switzerland. This article is an open access article distributed under the terms and conditions of the Creative Commons Attribution (CC BY) license (https:/ / creativecommons.org/licenses/by/ $4.0 /)$.

\begin{abstract}
In the last decade, game-based learning has received growing attention in educational contexts in general and science education in particular. A recent game trend, which has also found its way into STEM classrooms, is escape rooms. In this type of game, players have to work through several puzzles to achieve a specific goal (mostly to escape from an actual room). We conducted a systematic literature review to find out whether the "market" for such games is already saturated or if there is still potential for further development. After searching the common databases (ERIC, Web of Science, and Google Scholar, as well as the German database FIS Bildung), we analyzed 93 journal articles, book chapters, and conference papers in English and German from the following domains: chemistry, physics, biology, mathematics, computer science, general science (interdisciplinary), environmental science, and medicine. We selected the ones that targeted a specific educational level (primary, secondary or tertiary education) and were designed for formal educational settings. It transpired that there is a need for more easily adaptable escape rooms as well as for more empirical evidence on their actual effects.
\end{abstract}

Keywords: gamification; escape room; review

\section{Introduction}

Gaming is a universal phenomenon. Baby animals and human children play games in which they test and get to know their bodies and the surrounding world. They play just for the sake of playing - without knowing anything about the game's features or effects. The concept of playing is a fundamental part of human activity and can be found in various forms in all cultures and societies around the world [1]. When it comes to the effects of playing, prominent psychologists and educational researchers such as Montessori and Piaget have acknowledged the value of playing for the development of children over hundreds of years [2]. Vygotsky (1980) described games as providing opportunities for children to experience scenarios they are not yet able to live through in real life [3]. Thus, the importance of games for one's development has led to the inclusion of game-based settings for learning purposes [4] both in lower and upper secondary as well as in higher education. When studying the extensive literature on gamification and game-based learning it becomes obvious that the educational goals described in the literature are quite diverse, ranging from the promotion of content knowledge over motivation towards fostering collaboration and argumentation skills [5]. On the other hand, the evidence on actual learning outcomes fostered by games remains quite inconsistent [6]. Nevertheless, there undoubtedly are positive effects of educational games, such as an increase of motivation, as well as some quality criteria which can help to create games which are not only entertaining but also promote specific educational goals [7].

The literature indicates that game-based learning has received increasing attentionsome researchers even consider educational games to be one of the biggest "hypes" of the last decade in the educational context [8] (p. 5). Game-based learning (GBL) [9] embraces activities which employ game mechanics for learning purposes, which leads us to the 
concept of gamification. Gamification is commonly defined as the changing of processes that are not games through the implementation of a game or at least elements of one [10]. Here, game mechanics are explicitly used to follow concrete educational goals and solve specific problems [4].

Commonly mentioned elements for gamification in learning and education are story, dynamics, mechanics, collaboration, goal-oriented design, a set of rules, and technology [4,11] some of these are mostly applicable to digital games. However, this does not mean that specific elements must be used for gamification in learning and education, and using many gamification elements does not ensure more effective gamification or better results [12]. The challenge for educators is to choose necessary gamification elements to create an integrated solution that facilitates learning and education [4]. Based on the research findings available so far, Tsekleves et al., (2016) as well as Kim et al., (2018) developed several quality criteria that educational games should possess to increase the likelihood of motivational as well as educational outcomes. Games in educational frameworks should, among other things, be aligned with the curriculum, have clear learning goals like progression or repetition, be interactive, and contain aspects which can be used for assessment and feedback purposes thus allowing students to check their own progress [4,7].

Whoever plays steps out of their everyday experience and in a sense overrides it to immerse themselves in a game world. This phenomenon is addressed in the concept of the "flow theory" [13]. Here, the state of "flow" is described as a total absorption by a task which is both challenging and enjoyable. Such a totally immersive recent game trend is the so-called escape room. Escape rooms are a relatively new game concept that has been gaining popularity since around 2012 [14]. According to Nicholson (2015), an escape room is a physical adventure game in which the players have to work through various puzzles and tasks in a collaborative manner in order to achieve an overarching goal within a certain time limit [14]. Usually this consists of escaping from one or more rooms. Alternatively, the players must complete a specific task as part of the respective story, such as solving a criminal case or finding a hidden treasure. Before the game begins, the game master informs the players about the rules, the safety instructions, the general process, and the goal of the escape room. If there is a background story, the game master introduces the participants to the game, for example by reading an old diary entry. Then the door of the room is locked and the timer is started. Within the time limit, the players must use the objects they have discovered and decipher clues to solve the puzzles in order to advance in the game. During this time, the game master only acts as an observer and can provide assistance to the group if necessary. The game ends when the time runs out or the group has reached the goal. Over the course of the last decade, the game concept has been constantly further developed, characterized by an increase in the diversity of puzzles, a stronger integration of the story, thematically and technically more complex room design and, more recently, an increase in digitization $[15,16]$. In addition to physical escape rooms, due to their increasing popularity and the needs of different areas of application, other formats have been developed, including escape books, breakout boxes or home kits, augmented reality or virtual reality escape rooms, and digital escape games [17].

An integral part of escape rooms are puzzles. In commercial escape rooms, a distinction is made between two different types of puzzles: mental and physical puzzles [16]. To solve the first, clues must be discovered, deciphered, and related to each other. This requires cognitive skills and logical thinking. The counterpart to this are physical puzzles or tasks in which real objects or parts of the room have to be moved to find the solution. They are more time-consuming and represent cognitive relief. Both types of puzzles are also used in combination. Despite the variety of possible puzzles, three basic structural components can be identified: a problem, a hidden solution, and a reward [16]. To receive the reward, players must first decipher the puzzle and complete the resulting challenge. Often the solution is already hidden in the puzzle itself. The reward may include new puzzle pieces, clues or objects. 
Educational escape rooms represent a creative learning environment that combines formal and informal learning. The game concept is adopted, adapted to the needs of the target group, and linked to the required content-related and process-related skills. Educational escape rooms can be developed for all levels of educational institutions and for a wide variety of topics [18]. One of the primary goals of educational escape rooms is the playful learning of new subject matter and skills as well as the repetition, deepening, and transfer of existing knowledge. In addition, the students are made aware of the effects of their own behavior on themselves and others. Self-confidence, social interaction, and the appreciation of different perspectives are also strengthened [19]. In contrast to the regular tasks of the students, the puzzles in an educational escape room do not contain a directly visible work assignment. This is only implied and must first be developed by the learner with the help of the information [14], representing probably the biggest challenge both for students and teachers (who must step out of their comfort zone to allow such totally open settings). A school implementation of educational escape rooms requires an adaptation of the game concept due to the spatial conditions and the size of the learning group [14]. In contrast to commercial escape rooms, their school equivalent consists in $78.9 \%$ of cases of only one room [17]. Consequently, the objects placed in it must be clearly differentiated from the other objects in the room for the pupils, for example by marking them with a logo [20]. Due to the spatial and financial resources of the schools, educational escape rooms should be cost-efficient and spatially reversible, so that the thematic design of the room can only take place in a reduced form [21]. Educational escape rooms have great potential in the school context, regardless of the necessary modifications. The game concept is favored equally by both sexes, takes different learning styles into account, and is particularly suitable for interdisciplinary learning [14]. It is also a motivating, student-centered teaching method in which learners take responsibility for their own learning process. Teachers take on an observing role during the game as a game master. They may only provide support to a certain extent upon request from the pupils. This gives learners the opportunity to independently develop their own ideas, strategies, and solutions, to actively pursue them and, if necessary, to evaluate them. In addition, the pupils are encouraged to use their existing knowledge and skills in an unconventional way to solve the puzzles [19]. Such a student-active, playful approach promotes communication, collaboration, creativity, problem-solving skills, and critical thinking, and can have a positive influence on both the motivation and commitment of the students [16].

The game concept of the escape rooms has gained increasing popularity in the school context in general and in STEM education in particular in recent years. Hardly any science education journal has been without a corresponding article, and the topic has also been present at large international conferences. Thus, the following questions have arisen: what is the current status of the development of STEM-related escape rooms? Which goals do the escape rooms available so far pursue? For which educational levels as well as subjects are escape rooms mostly arranged? So far, no systematic reviews on this topic have been conducted. We analyzed the literature to answer these questions, identify research gaps, and shed light on whether the escape room hype can be considered outdated or whether there is still much to develop and to inquire.

\section{Materials and Methods}

We conducted literature database searches for the keywords "escape room", "exit game", "escape lab", "escape game", and "breakout" in combination with the STEM education domains science, chemistry, physics, mathematics, and biology education. The search was carried out using the Web of Science and ERIC database, as well as Google Scholar. The databases were selected purposefully. The Web of Science can be considered as the most scholarly based database only including quality journals that fulfill the criteria of being international, peer-reviewed, and recognized within the scientific community. ERIC is a database that also covers publications in education from other sources, like conferences. Google Scholar analyses all publications on the internet and ranks them according to a 
certain algorithm which mainly depends on their popularity. With this search there is no proof of complete comprehensibility, but it is suggested that there is chance that most of the relevant publications in this topic can be found. We also searched the German database "FIS Bildung" with the same keywords in German which led to 17 hits. The relevant ones (only two in total) had already been found in the international databases due to the fact that they had an English abstract. Thus, this review is limited to publications in English and German. Hits resulting from the combinations of all the above-mentioned keywords totaled 67 in ERIC and 96 in the Web of Science. Google Scholar alone yielded about 2750 hits for the timeframe 2007 and 2021. The search was conducted within the last two weeks of February 2021.

The results of ERIC and the Web of Science were individually analyzed. Prior to this, we formulated inclusion and exclusion criteria for the relevant publications. The inclusion criteria were as follows: we included all versions of educational escape games (tabletop, analogue/digital, books), which took place in a formal educational setting or an informal educational setting with a clear educational objective targeting preschool, primary, secondary, or higher education. The papers all contained a clear description of the setting (content, target group, format, types of puzzles) and were aimed at STEM education (chemistry, biology, physics, math, computer science, health care, medical, nursing and natural sciences in general). We excluded escape games that did not target a specific education level, escape games for informal learning settings such as camps, libraries, or fairs, those without content knowledge goals or content related skills, as well as articles including the keywords in the wrong context (such as breakout rooms within videoconferencing tools). We did not have access to some publications, particularly those from teacher journals.

This led to a total of 37 relevant articles or book chapters. Sixteen additional publications were found by chain-referencing. The first 650 Google Scholar search results were also screened, resulting in 40 additional articles leading to a total of 93 articles making up the foundation of this review. The selected material was first classified according to general criteria: (i) educational domain (primary education, secondary education, tertiary education); and (ii) the topics covered (general science or a specific science/STEM subject such as medicine, chemistry, physics, biology or mathematics). Eight of the suggested settings were intended for primary education, 31 for secondary, and 58 for tertiary education (some of the papers were aimed at both secondary and tertiary levels). Table 1 shows the distribution among the domains. In a second round of categorization, the criteria chosen were learning objectives, theme, group size, format, organization of the puzzles, as well as the role of the teacher/instructor. The issue of reliability was approached by cross-checking of the coding among the authors. The examples selected for illustrating the analysis were chosen with respect to the type of publication: peer-reviewed articles in journals and books were given priority to other types of publications.

Table 1. Overview of the domains of the reviewed escape rooms (one of the publications was intended both for chemistry and physics lessons).

\begin{tabular}{cccccccc}
\hline Chemistry & Physics & Biology & Maths & $\begin{array}{c}\text { Computer } \\
\text { Science }\end{array}$ & $\begin{array}{c}\text { General } \\
\text { Science }\end{array}$ & $\begin{array}{c}\text { Environmental } \\
\text { Science }\end{array}$ & Medicine \\
\hline 15 & 6 & 4 & 13 & 13 & 5 & 2 & 35 \\
\hline
\end{tabular}

\section{Results of Educational Escape Rooms in STEM Education}

The first very noticeable result of our research was the large number of publications in the field of medicine (see Table 1). Escape rooms seem to be very common especially for the academic training of nurses. When it comes to the STEM domains, most of the examples were found for chemistry education, followed by mathematics and physics. The majority of the suggested games were intended for a collaborative approach with the students being divided into groups (ranging from two to ten people with the average being five students). 
Thus, most of the games could be adopted in different class sizes. Only very few settings were aimed at single players. The play time ranged from $15 \mathrm{~min}$ to an entire day, with the average duration being $60 \mathrm{~min}$. Analog settings prevail over solely digital ones: 12 chemistry, 2 biology, 1 general science, and all 6 physics escape games included experiments or lab-based activities. Few of the games only involved the simulation experiments in a digital learning environment. Only one escape lab was found. Nearly all escape rooms related to nursing, pharmacy, or medicine were designed as a simulation laboratory, where participants needed to apply lab and clinical skills in a realistic setting. When it came to the types of puzzles involved, crossword puzzles, mathematical tasks, and patterns were often used. The locks were mostly alphabetical or used numbers. The Supplementary Materials for this paper contain a table summarizing the main features of each escape room (e.g., types and number of puzzles, number of players, duration, domain, etc.).

\subsection{Educational Escape Rooms in Chemistry Education}

As already mentioned, a total of 15 publications were found dealing with escape rooms in secondary and tertiary chemistry education. Only seven of the papers targeted a specific topic and not a combination of several ones. The topics addressed were safety practices in the lab [22], structures and traits of polymers [23], the periodic table [24], the Leblanc process [25], chemical bonding [26], the galvanic cell [27], and the Solvay process [28]. The breakout activity by Nephew and Sunasee (2021) was created for academic institutions in order to make the obligatory safety training more interactive and engaging [22]. The goal of the activity is to open an actual box with three locks. The locks have to be opened using two different codes (numeric and alphabetic) and a key which is hidden in the laboratory. To open the locks, the participants must fulfill three hands-on activities: spill training, emergency response training, as well as waste disposal. In the first activity the players must come up with an order of contents of a spill kit to get rid of a reagent spill. Each content has an assigned letter which in the end makes up the code. This is generally a very common puzzle type for educational escape rooms. The puzzle on emergency response uses fluorescent clue numbers for which you need a black light flashlight to unveil themsuch little "playful" elements are also frequently used to make a setting more motivating and challenging. In the escape room on chemical bonding by Ang, Ng and Liew (2020) the first-year general chemistry students had to complete four puzzles (one group of students per puzzle) and a final collaborative puzzle at the end. Each group had to unveil a number for the combination lock. In one of the puzzles, the students had to compare the strengths of different bonds with the help of a model experiment using magnets with the strongest bond being the ionic one. Since "ionic" is spelled with five letters, the hidden number turns out to be five. A rather original idea and a different way of implementing the escape game context comes from Strippel, Schröder, and Sommer (2021) who constructed an escape box. The box is locked and can be opened by constructing a simple galvanic cell with a specific voltage. The voltmeter is connected to a microcomputer which controls the locking mechanism. As soon as the correct voltage is reached, the box is unlocked, and the reward can be retrieved [27].

Two escape rooms covered different aspects from a specific chemical sub-domain, namely analytical chemistry [29] and organic chemistry [30], with the first one being aimed at tertiary education. The setting by Groß and Schumacher (2020) covers main organic chemistry topics from the German secondary school curriculum (alcohols, aldehydes, carboxylic acids, coloring agents, esters) with one puzzle per topic. Thus, this experimental escape room setting can be used to review and consolidate the content knowledge. The context of this proposal is the kidnapping of a chemistry lecturer. The players are supposed to use his labor journal, which is also the structuring element of the game, to decipher the research, track down the kidnapper, and rescue the protagonist [30].

The remaining six proposals combined several thematic aspects from different domains of chemistry. Clapson et al., (2020) designed an escape game in a box format containing four hands-on activities on the following general chemistry topics: thin layer 
chromatography, buoyancy, density, and a galvanic cell made out of zinc and copper [31]. For instance, in the activity on buoyancy, the learners compared the buoyancy of several pipettes in a plastic bottle filled with water. The correct order of the pipettes leads to a code that unlocks the next puzzle in the box. In the puzzle using a galvanic cell, the microscale cell is used to light up LEDs which are numbered. The numbers can then also be used for the lock. From our point of view, such scenarios can be difficult to adapt by other institutions due to the fact that the exact combination of these contents is needed.

\subsection{Educational Escape Rooms in Maths Education}

Out of the 13 publications, 7 targeted escape games in secondary math education, followed by primary (4) and tertiary (3). Escape games within the mathematical domain mainly fall into two subcategories: algebra [32] and geometry [33,34]. Algebra-themed escape games dealt with linear and quadratic equations [35], systems of equations [36], slope [37] and polynomials [38]. Geometry-themed escape games mainly addressed trigonometry [39], magnitudes and measurements [33,34,40]. The escape game of Arvanitaki and Skoumpourd (2019) is specially designed to teach students with visual impairment the concept of length [34]. To escape from the museum, they have to calculate and measure the distances between objects with their own steps and find specific measurement tools in the room. Movement and sense of touch are very important for understanding the concept of space and the properties and relationships of the objects in it. Therefore, the escape room is heavily dependent on physical tasks and uses a touchable roadmap and a SmartGuide obstacle detection device, so that students can navigate within the room. Additional topics addressed in the publications include logic [41], rational numbers [42] and calculus and cryptography [43]. Only one escape game does not specify its content-related learning objectives, saying it is based on the third grade curriculum [44]. Students take over the roles of investigators trying to unlock the case and disable the bomb. All teams have to work together and interact with veteran investigators, played by a group of parents. This collaborative approach is possible due to a multi-linear puzzle path, resulting in a meta-puzzle to unlock the bomb case. Small prizes and third grade certificates are handed out as rewards. An interdisciplinary approach can be found for two math escape games. Moura and Santos (2019) designed an analog escape game for the 7th grade combining the subdomain algebra with Portuguese literary work [32]. In "MathEscape", proposed by Galvas and Stascik (2017), students have to steal the solution of an old mathematical problem from the minister's office by solving 28 tasks. Nine tasks are non-mathematical, interdisciplinary tasks, such as mixing colors (arts), optic puzzles (physics), space orientation (physical education), comprehension (language), morse code (music), and using the periodic table (chemistry). In addition, mathematical tasks are used to revise and systemize knowledge about linear and quadratic equations. The research focuses on how the game enhances students' attitudes towards mathematics [35]. One digital and three hybrid math escape games were found, consisting of analog puzzles and digital locks [42], programmed puzzles and physical props [41], or augmented elements. Queiruga-Dios et al., (2020) designed an augmented, card-based escape game using the HP Reveal App to overlay specific images and objects [43]. When students scanned game items, they discovered videos, links, and other interactive elements. At the beginning a roadmap was given out, containing the game introductions, hint approach, puzzle path, and instructions. The goal is to stop a virus called WannaCry by unlocking the physical breakout box. For this, each color-coded group (blue, yellow, red, and green) had to solve three puzzles based on linear algebra, cryptography, or calculus. The second puzzle could only be solved if all groups worked together. An option to modify the game, so that the groups can compete against each other, is also given. Some escape games assign roles to the students in order to improve collaboration and structure the activity, e.g., resource manager, recorder/reporter, facilitator, or task manager [40,42]. This is mostly the case for primary or lower secondary escape games where self-organization within the groups may be more challenging for the learners. In most escape games that we reviewed hints are provided by the teacher in oral 
form upon students' request. In some cases, hints are incorporated into the game materials in the form of clue cards [43], hintbooks [40] and hints in exchange [36]. Fuentes-Cabrera, Parra-González, López-Belmonte, and Segura-Robles (2020) designed a physical escape room with timed puzzles, meaning each puzzle had to be solved within a certain time limit [36]. If the time ran out before students solved the puzzle, they received a clue or a new puzzle. For each puzzle solved within the time limit students earned a badge, which they could exchange for a hint or extra points. The escape activity covers a whole teaching unit consisting of five linear puzzles. Puzzles, props, and clues were color-coded for each group, which seemed a great way to allow multiple groups to play the escape room at the same time.

\subsection{Educational Escape Rooms in Physics Education}

All six publications targeted secondary education. The escape games addressed the following topics: photovoltaic effect [45], physics of fluids [46,47], anti-matter [48] and electromagnets [49]. Monnot, Laborie, Hérbrard, and Dietrich (2020) do not specify the learning objectives of the described escape games [50]. The publication features a game maker approach, so different physical escape rooms and labs were designed by the students in groups of 5 to 10. Each of their escape rooms consisted of at least one locked box containing the exit key, included lab-based activities and targeted general chemistry and physics knowledge. Clues, videos, and detailed instructions were provided through a tablet. Two publications featured digital escape games. Hou and Chous (2012) developed a digital escape chamber where the students had to assemble an electromagnet and use it to get the key [49]. Fotovolt is a 2D point-and-click escape game for upper secondary education designed by Tulha, de Carvalho, and Coluci (2019) [45]. The game is based on constructionism theory and is integrated into a remote physics lab. A narrative or game goal is not mentioned, but there are six game phases dealing with the properties of light, electric energy, conductive materials, energy conversion, tension, and angulation. Two physical escape rooms addressed the physics of fluids, but contained different subtopics, like speed of efflux [47] or Pascal's law [46]. They both consisted of five linear puzzles and used envelopes as locks. Some physical escape games with hands-on or lab-based activities required advanced equipment, such as 3D pointers, x-ray machines or semiconductors [48], which makes them difficult for use in other educational settings. All mentioned physics escape games included lab-based activities.

\subsection{Educational Escape Rooms in Biology Education}

The biology escape games (3) were mainly designed for secondary education. Primary education was not targeted in our sample. Only Brady and Andersen (2019) developed a physical escape room for university students to review the course concepts of genetics analysis before the final exam [50,51]. In line with the learning objective, the theme firefly genetics was chosen. The proposed game cannot be played by multiple groups at the same time, due to the excessive use of physical space and props. In comparison to other escape rooms, the teacher had a more active role, verifying answers, giving instructions at specific stages of the game, guiding struggling groups, and handing out props, keys, and posters as puzzle rewards. The authors see the game master role of the teacher as a great way to observe students' problem solving and assess their aptitudes. Escaping from one or more rooms was the most popular goal for escape rooms in general. This was not the case for the biology escape games. The game goal in the biology domain was either to discover a secret [52], solve a crime [53], or to prove your worth and receive the Nobel Prize [51]. Bartlett and Anderson designed a tabletop escape game about decomposers and the process of decomposition. The narrative is set in a dystopian world where nearly all viable topsoil is lost. The only hope for mankind is to discover the secret research results of the shutdown lab. To solve the six puzzles students sorted pictures of "trash" (e.g., broken glass, a soda can, a tea bag), played a card game simulating the decomposition of different objects or calculating the C:N ratio. Customizable password-protected QR-codes 
were generated as digital locks using QuickMark. This reduced the need for padlocked boxes and enabled the development of an entirely print-and-play version of the game. Healy (2019) also designed a tabletop escape game about entomology, including lab-based activities and live insects [53]. Students learn how insects can cause death and disease in humans and animals by solving a murder mystery and saving the falsely convicted John. Instruction cards and a set number of hint tokens are used, so that the teacher does not need to act as the game master. "The room of keys", developed by Mystakidis, Cachafeiro, and Hatzilygeroudis (2020), is an award-winning digital escape room about the structure and function of enzymes [54]. Prior to solving puzzles, students walk through a tutorial and expositional phase. The overall game play takes about $15 \mathrm{~min}$. In addition to the tutorial phase the game includes simulated lab-based activities. The game provides audio and visual information to cover different learner types.

\subsection{Educational Escape Rooms in Computer Science Education}

More than half (7) of the 13 publications in the field of computer science targeted higher education, followed by secondary (4) and primary education (2). All of the publications aimed at promoting computational thinking (CK) as well as computer science problem solving [55]. Some common features of computational thinking include the logical organization and analysis of data, automated problem solving, and high efficiency as well as transferability of results [56]. In the scenario by Kahila, et al. (2020), for primary education, physical and virtual elements were combined [57]. The story of the game is that the children are sent to the Earth's orbit in a spaceship due to the fact that humankind has failed to stop climate change rendering the living conditions on Earth unhabitable. Now that the conditions have been restored, the children must solve some technical problems with the spaceship and plan how to land it safely. Many of the puzzles-mostly minigames-were hidden behind QR-codes distributed in the room. Due to the young target group, the games provided first insights into computational thinking - understanding of binary logic, basic ideas of program execution, decrypting codes, and so on. For instance, in one of the games the players had to find the most energy efficient route from the generator to the engines. In an escape room for 10th graders by Hacke (2019) students were sent on a spy mission [55]. They needed to identify the tasks of the next computer science exam stored on a tablet protected by a password and an alarm system in the room. The students had to solve three puzzles, for instance decrypting an encoded message, to unlock the tablet. One of the hints involved a digital camera which (after the memory card for it has been found) contained photos of objects in the room leading to further clues. López-Pernas et al., (2019) describe an educational escape room for higher education in a programming course (HTML, CSS, JavaScript etc.) for Bachelor students [58]. This game aimed at improving the students' knowledge of programming concepts. The story was built upon the challenge to decipher the genetic code of a vaccine against a deadly virus. The data leading to this code was contained in an unfinished application which was developed using the computer languages from the course. The students then had to rebuild the application and gain access to the code. While the games for primary and secondary education mainly focus on general computational thinking, this is an example of how scenarios for higher education include the content of the respective course.

\subsection{Educational Escape Rooms in General Science and Enviromental Science}

A total of five papers from the field of general science (STEM education) were identified in our review, three of them for secondary education. Veldkamp et al., (2020) designed an escape box for 15-16-year-old students containing analog and digital puzzles on different topics and socio-scientific issues such as climate change, plastic soup or infectious diseases [59]. The only proposal for primary education was published by Lin, Wang, Zhung and Wang (2017) [60]. They designed a fully digital escape room on the science behind papermaking. One scenario for higher education [61] focused on pre-service teachers as well as general concepts of astronomy (planets, satellites, etc.), mathematics (radius, perimeter), 
and science (density), under the overarching theme of sustainability. In an online setting, the pre-service teachers had to use their knowledge on these topics to complete a challenge given to them by the scientist Carl Sagan.

The two proposals from the field of environmental science both focus on higher education. Pater (2020) developed a game called "Unlock the Future" with the goal to increase the environmental attitudes and efficacy beliefs of the players [62]. The players need to "travel back in time" to stop climate change and save the earth. Chang (2019) followed a similar approach (dystopian future) but focused more on issues surrounding waste disposal [63].

\subsection{Educational Escape Rooms in Medicine}

As mentioned above, we were surprised by the numerous publications from the field of medicine (see Table 1). At this point, we would like to give a brief insight into the escape rooms in this domain. Many of the proposals (16) focus on the education of nurses. These games mainly focus on consolidating basic, routine procedures and concepts which frequently appear in a typical nursing working environment, for instance, the interpretation of laboratory results [64], improvement of patient care [65], or basic skills in clinical practice such as handling protective equipment or maintaining hand hygiene [66]. In a scenario called "operation outbreak", Frederick and Reed (2021) built upon the non-satisfactory results of a nursing exam and included content areas where scores had been the lowest (environmental cleaning, Spaulding classification, phases of anesthesia, surgical hand scrub, wound classification, patient safety, wound closure) [67]. In one of the eight puzzles, for example, the nurses had to put the steps of a surgical hand scrub in the correct order. After the intervention, an improvement in exam scores was observed.

Other escape rooms targeted medical, dentistry, and pharmacy students or healthcare professionals, also targeted at routine skills. In later professional life, these skills are often required to be carried out in certain stressful situations and under time pressures, just as in the game. From our point of view, this is one of the main reasons for the popularity of escape game format in the medical realm. Wilby and Kremer (2020) designed a short (five puzzles/quiz-based activities) escape room on basic knowledge of cancer and cancer treatment for medical students [68]. In one of them, the players had to find symptoms of non-Hodgkin's lymphoma in the room, distinguish them from other symptoms, and put them in a specific order to obtain a code. In a game by Sanders, Kutzin, and Strother (2021), the players (healthcare workers) were locked in the simulation room by a serial killer and needed to escape by applying their knowledge of anion gap metabolic acidosis, pneumothorax, chest tube insertion, use of an ultrasound machine, as well as Brose low tape for pediatric resuscitations [69]. Among other activities, the players had to arrange a series of radiographs in the correct order or make a laryngoscope work by finding missing batteries.

\subsection{Empirical Research on the Effects of EER}

Most of the reviewed publications describe specific game scenarios with little, if any, evidence on their effectiveness. For example, Clapson et al., (2020) use a simple evaluation questionnaire with questions such as "If you could repeat this activity, what would you do differently?" for the test subjects' initial assessment of the game [31]. López-Pernas et al., (2019) argue that previous works on educational escape rooms have "failed to assess the impact of this sort of activities in terms of learning effectiveness" (p. 184221). However, learning effectiveness is not the only thing that may theoretically be measured using statistical tests or assessed using qualitative methods-aspects such as motivation, interest, student activation, and others may also be evaluated.

López-Pernas et al., (2019) used a pre-post-test research design to assess the learning effectiveness of their scenario [58]. The score difference was not only statistically significant but showed (especially for educational studies) a sizeable Cohen's d effect size (0.73). Chang (2019) implemented a control and treatment group design in a quite large undergraduate 
course $(n=452)$ to test the effectiveness of her environmental science escape room [63]. She conducted focus group interviews after the game and used a pre- and post-questionnaire on environmental values, behaviors, and sense of agency, concluding that no significant differences between the two groups had been found when it came to changes in values, but significant differences were present as regards behavior changes. Only Chang (2019), as mentioned above, and Fuentes-Cabrera et al., (2020) used a control and treatment group design. The latter conducted an ad hoc questionnaire consisting of 32 items to research gender differences and a possible correlation between the dimensions achievement, anxiety, motivation, and autonomy. The authors found a statistically significant improvement of all four research dimensions in both groups, with the treatment group achieving higher results than the control group. Neither gender differences nor any kind of correlation could be found in the control group, whereas women had the highest level of anxiety and were the most motivated in the treatment group. At the moment there is no clear empirical evidence on the learning effect of escape games in comparison to a more traditional, lecturebased learning approach using a control and treatment group design. Some studies use previously established instruments to evaluate their games. Pater (2020) used the wellestablished GUESS scale [70] with nine subscales, including enjoyment, social connectivity, and visual aesthetics. Lin et al., (2017) used Kiili's flow scale (2006) [71] to measure the learners' state of flow, which turned out to be high. Yllana-Pietro, Jeong, and GonzálezGómez (2021) implemented a pre-post questionnaire measuring attitude, self-efficacy, and emotions towards science by running several statistical tests [61]. They observed an increase in positive attitude and high self-efficacy items, as well as the emotions "joy", "satisfaction" and "fun", but also negative emotions such as "nervousness" due to the unfamiliar online setting. There are quite a few studies using pre-post surveys or tests to measure the potential learning effect or affective outcomes, such as motivation, interest, and engagement, e.g., [43,51,54,60-63]. In particular, Berthod, Bouchoud, Grossrieder, Falaschi, Senhaji, and Bonnabry (2020) and Eukels' publications are to be mentioned. Berthod et al., (2020) found a significant increase in correct answers after the escape game activity. One month later, the same post-test was conducted again. Even then, $80 \%$ of the given answers were correct compared to $50 \%$ of correct answers in the pretest [72]. Eukel and his fellow researchers have developed multiple escape games for medical disciplines and researched their impact on students' content knowledge [73,74]. For example, Caldas, Eukel, Matulewicz, Fernández, and Donohoe (2019) conducted a pre- and post-assessment test. The post-test included the content-related questions of the pretest and an additional perception questionnaire. The assessment score improved significantly from $50 \%$ to $83.3 \%$. To research whether escape games have a long-lasting learning effect, multiple post-tests need to be undertaken at different time intervals. It should be mentioned that none of the analyzed publications have researched which game components exactly influence students learning in a positive way. Therefore, thus far it cannot be postulated why the use of educational escape games benefits learning.

Some researchers rely on qualitative data to analyze students' interactions or to gain information that can potentially help to improve the game design. In a design-based research approach [75], Veldkamp et al., (2020) used classroom observations to evaluate the state of immersion of the students and formulate design principles for educational escape rooms [59]. Hacke (2019) conducted a video analysis of the students while playing (with over 200 participants) and analyzed the videos to identify participants' success in problem solving. In advance, he operationalized specific behaviors (e.g., systematic search for clues) that allowed for conclusions on the problem solving strategies [55].

\section{Discussion and Conclusions: Identifying (Research) Gaps}

As outlined above, playing and learning are closely connected, therefore, gamification in general as well as educational escape rooms in particular can be considered a "hot topic" in the STEM education community. Our literature review has shown that numerous proposals for the implementation of educational escape rooms in the field of STEM have 
been published, especially in the last five years. Nevertheless, we were able to identify some gaps in the research and development on this topic. First of all, there is still a need for new proposals mainly in the subjects of physics and biology. Additionally, interdisciplinary scenarios covering several domains, as well as games from the field of environmental science, are still missing. Generally, there is a lack of interdisciplinary approaches. A positive finding is that most of the chemistry, physics, and biology settings use experiments to make the learning experience more varied and promote specific experimental skills which are highly relevant in these subjects. On the other hand, educators could consider creating games that are more simple, easily adaptable, less time-consuming games, and without the use of experiments. Our impression was that the escape rooms published so far were mainly adapted to the needs of a specific course or institution - this is understandable but limits the transferability of such proposals to other institutions and learning groups. The STEM education community would certainly benefit from a more systematic approach when it comes to covering standard school or higher education topics which are taught all around the world. As regards the levels of education for which the proposals are designed, most of them targeted tertiary education, so there is a great potential for development especially in the field of secondary education (and also primary education). Such a systematization can be achieved by several steps. First, we suggest implementing a database where all educational escape rooms available are collected and can be easily browsed-our review could be a starting point for this. Second, there is a need for a set of design principles for educational escape rooms. Veldkamp et al., 2020 outlined a first proposal on this issue which can serve as a basis for further discussions. Finally, there is a general need for more empirical evidence. Many of the publications we found were small-scale studies that used observations or feedback questionnaires. From our point of view, the following aspects can be of research interest: studies on how educational escape games affect motivation, collaboration, creativity, and problem solving; research on games that are set up to identify students' misconceptions or to confront them; as well as research on the effects of educational escape rooms for knowledge acquisition. Here, the potential research questions highly depend on the goals of the respective escape rooms. We realize that the goals differ depending on the domain. They vary from the promotion of content knowledge and scientific thinking (e.g., in chemistry, biology, or physics) to computational thinking (computer science) or the consolidation of routine procedures (medicine). Some of the available escape games are designed to be played remotely. It would be interesting to inquire as to whether such scenarios have comparable effects to live, physical escape rooms. When it comes to the technical implementation of the scenarios, we can say that while some of the games used digital settings, most of them can be considered to be quite low-tech. The potential future inclusion of virtual reality or augmented reality technologies will lead to new research interests on immersive learning environments with almost no spatial limitations.

In summary, educational escape rooms seem to be an engaging way to "gamify" STEM learning, however a much more systematic approach as well as more evidence is needed. Thus, educational escape rooms are not a declining trend yet, but scholars need to fill these existing gaps and create broadly adaptable frameworks in order to make full use of the potential of such teaching and learning scenarios.

Supplementary Materials: The following are available online at https:/ /www.mdpi.com/article/10 .3390 /educsci11060308/s1. Here we can provide a table showing all the analyzed results together with a short description of each escape room.

Author Contributions: Conceptualization, C.L. and N.B.; methodology, C.L. and N.B.; investigation, C.L. and N.B.; writing—original draft preparation, C.L. and N.B.; writing—review and editing, C.L. and N.B. All authors have read and agreed to the published version of the manuscript.

Funding: This research received no external funding.

Institutional Review Board Statement: Not applicable. 
Informed Consent Statement: Not applicable.

Conflicts of Interest: The authors declare no conflict of interest.

\section{References}

1. Roberts, J.M.; Arth, M.J.; Bush, R.R. Games in Culture. Am. Anthr. 1959, 61, 597-605. [CrossRef]

2. Murray, J. The play's the thing. Int. J. Early Years Educ. 2017, 26, 335-339. [CrossRef]

3. Vygotsky, L.S. Mind in Society: The Development of Higher Psychological Processes; Harvard University Press: Cambridge, MA, USA, 1980.

4. Kim, S.; Song, K.; Lockee, B.; Burton, J. What is Gamification in Learning and Education? In Gamification in Learning and Education; Springer Science and Business Media LLC: Berlin/Heidelberg, Germany, 2018; pp. 25-38.

5. Martinez-Garza, M.; Clark, D.B.; Nelson, B.C. Digital games and the US National Research Council's science proficiency goals. Stud. Sci. Educ. 2013, 49, 170-208. [CrossRef]

6. Young, M.F.; Slota, S.; Cutter, A.B.; Jalette, G.; Mullin, G.; Lai, B.; Simeoni, Z.; Tran, M.; Yukhymenko, M. Our Princess Is in Another Castle. Rev. Educ. Res. 2012, 82, 61-89. [CrossRef]

7. Tsekleves, E.; Cosmas, J.; Aggoun, A. Benefits, barriers and guideline recommendations for the implementation of serious games in education for stakeholders and policymakers. Br. J. Educ. Technol. 2014, 47, 164-183. [CrossRef]

8. Raitskaya, L.; Tikhonova, E. Gamification as a Field Landmark in Educational Research. J. Lang. Educ. 2019, 5, 4-10. [CrossRef]

9. Gros, B. Digital Games in Education. J. Res. Technol. Educ. 2007, 40, 23-38. [CrossRef]

10. Deterding, S.; Dixon, D.; Khaled, R.; Nacke, L. From game design elements to gamefulness. In Proceedings of the 15th International Academic MindTrek Conference on Envisioning Future Media Environments-MindTrek '11, Tampere, Finland, 28-30 September 2011; Association for Computing Machinery (ACM): New York, NY, USA, 2011; pp. 9-15.

11. Aynsley, S.; Nathawat, K.; Crawford, R.M. Evaluating student perceptions of using a game-based approach to aid learning: Braincept. High. Educ. Pedagog. 2018, 3, 478-489. [CrossRef]

12. Mora, A.; Riera, D.; González-González, C.S.; Arnedo-Moreno, J. Gamification: A systematic review of design frameworks. J. Comput. High. Educ. 2017, 29, 516-548. [CrossRef]

13. Csikszentmihalyi, M. Flow: The Psychology of Optimal Experience; Harper \& Row: New York, NY, USA, 1990.

14. Nicholson, S. Peeking behind the Locked Door: A Survey of Escape Room Facilities, 2015, White Paper. Available online: http:/ / scottnicholson.com/pubs/erfacwhite.pdf (accessed on 18 May 2021).

15. Nicholson, S. Ask Why. Creating a Better Player Experience through Environmental Storytelling and Consistency in Escape Room Design. Paper Presented at Meaningful Play, East Lansing, Michigan, USA, October 2016. Available online: http: //scottnicholson.com/pubs/askwhy.pdf (accessed on 18 May 2021).

16. Wiemker, M.; Elumir, E.; Clare, A. Escape Room Games. In Game Based Learning-Dialogorientierung und Spielerisches Lernen Digital und Analog; Haag, J., Wießenböck, J., Gruber, W., Freisleben-Teutscher, C.F., Eds.; Fachhochschule St. Pölten GmbH: St. Pölten, Austria, 2015; pp. 55-68.

17. Fotaris, P.; Mastoras, T. Escape Rooms for Learning: A Systematic Review. In Proceedings of the 13th International Conference on Game Based Learning, ECGBL, Odense, Denmark, 3-4 October 2019; Elbaek, L., Majgaard, G., Valente, A., Khalid, S., Eds.; Academic Conferences and Publishing International Limited: Reading, UK, 2019; pp. 235-243.

18. LookingatLearning. EDUESC@PEROOM: Manual Report for Educators. Available online: https://drive.google.com/file/d/0B2 3HzLyhtRAMUGtYQmJtMWM1UVk/view (accessed on 26 April 2021).

19. LookingatLearning. EDUESC@PEROOM: Tutorial. Available online: https://drive.google.com/file/d/0B23HzLyhtRAMbGJzLVk0 aHlGeFk/view (accessed on 26 April 2021).

20. School Break. Using Escape Rooms in Teaching. Available online: http://www.school-break.eu/wp-content/uploads/2020/03/ SB_Handbook_1_eER_use_in_teaching.pdf (accessed on 26 April 2021).

21. Sundsbø, K. Open Access Escape Room: The key to OA engagement? Insights UKSG J. 2019, 32, 1-7. [CrossRef]

22. Nephew, S.; Sunasee, R. An Engaging and Fun Breakout Activity for Educators and Students about Laboratory Safety. J. Chem. Educ. 2021, 98, 186-190. [CrossRef]

23. Gilbert, B.C.T.; Clapson, M.L.; Musgrove, A. ChemEscape, Polymer Chemistry: Solving Interactive Puzzles Featuring Scaffolded Learning to Promote Student Understanding of Polymers and Structure-Property Relationships. J. Chem. Educ. 2020, 97, 4055-4062. [CrossRef]

24. Yayon, M.; Rap, S.; Adler, V.; Haimovich, I.; Levy, H.; Blonder, R. Do-It-Yourself: Creating and Implementing a Periodic Table of the Elements Chemical Escape Room. J. Chem. Educ. 2019, 97, 132-136. [CrossRef]

25. Dietrich, N. Escape Classroom: The Leblanc Process-An Educational "Escape Game". J. Chem. Educ. 2018, 95, 996-999. [CrossRef]

26. Peleg, R.; Yayon, M.; Katchevich, D.; Moria-Shipony, M.; Blonder, R. A Lab-Based Chemical Escape Room: Educational, Mobile, and Fun! J. Chem. Educ. 2019, 96, 955-960. [CrossRef]

27. Strippel, C.G.; Schröder, T.; Sommer, K. Ein Lehr-Lern-Mittel für elektrochemische Experimente im Eigenbau: Experimentelle Escape Box. Chem. Unserer Zeit 2021, 55, 1-7. [CrossRef]

28. Estudante, A.; Dietrich, N. Using Augmented Reality to Stimulate Students and Diffuse Escape Game Activities to Larger Audiences. J. Chem. Educ. 2020, 97, 1368-1374. [CrossRef] 
29. Ferreiro-González, M.; Amores-Arrocha, A.; Espada-Bellido, E.; González, M.J.A.; Vázquez-Espinosa, M.; González-De-Peredo, A.V.; Sancho-Galán, P.; Álvarez-Saura, J.Á.; Barbero, G.F.; Cejudo-Bastante, C. Escape ClassRoom: Can You Solve a Crime Using the Analytical Process? J. Chem. Educ. 2019, 96, 267-273. [CrossRef]

30. Groß, K.; Schumacher, A. Chemistry Escape-Finde den Weg. Chem. Unserer Zeit 2020, 54, 126-130. [CrossRef]

31. Clapson, M.L.; Gilbert, B.; Mozol, V.J.; Schechtel, S.; Tran, J.; White, S. ChemEscape: Educational Battle Box Puzzle Activities for Engaging Outreach and Active Learning in General Chemistry. J. Chem. Educ. 2019, 97, 125-131. [CrossRef]

32. Moura, A.; Santos, I.L. Escape Room in Education: Gamifying learning to engage students and learn Maths and Languages. In Experiences and Perceptions of Pedagogical Practices with Game-Based Learning and Gamification; Silva, B.D.d., Lencastre, J.A., Bento, M., Osório, A.J., Eds.; CIEd: Braga, Portugal, 2019; pp. 179-194.

33. Arnal-Palacián, M.; Macías-García, J.A.; Duarte Tosso, I. Escape Rooms as a Way to Teach Magnitudes and Measure in Degrees in Education. In Proceedings of the 8th International Conference New Perspectives in Science Education, Florence, Italy, 21-22 March 2019; Pixel, Ed.; Filodiritto: Bologna, Italy, 2019; pp. 79-84.

34. Educational Escape Room for Approaching the Concept of Length on Blind Students. In Proceedings of the 12th European Conference on Game Based Learning, Sophia Antipolis, France, 4-5 October 2018; Academic Conferences International Ltd: Reading, UK, 2019; pp. 832-838.

35. Glavaš, A.; Staščik, A. Enhancing positive attitude towards mathematics through introducing Escape Room games. In Mathematics Education as a Science and a Profession; Kolar-Begović, Z., Kolar-Šuper, R., Jukić Matić, L., Eds.; ELEMENT: Osijek, Croatia, 2017; pp. 281-294.

36. Fuentes-Cabrera, A.; Parra-González, M.E.; López-Belmonte, J.; Segura-Robles, A. Learning Mathematics with Emerging Methodologies-The Escape Room as a Case Study. Mathematics 2020, 8, 1586. [CrossRef]

37. Stohlmann, M.S. Escape Room Math: Luna's Lines. Math. Teach. 2020, 113, 383-389. [CrossRef]

38. Jiménez, C.; Arís, N.; Ruiz Ángel, A.M.; Orcos, L. Digital Escape Room, Using Genial.Ly and A Breakout to Learn Algebra at Secondary Education Level in Spain. Educ. Sci. 2020, 10, 271. [CrossRef]

39. Sánchez-Martín, J.; Corrales-Serrano, M.; Luque, A.; Zamora-Polo, F. Exit for success. Gamifying science and technology for university students using escape-room. A preliminary approach. Heliyon 2020, 6, e04340. [CrossRef]

40. Charlo, J.C.P. Educational Escape Rooms as a Tool for Horizontal Mathematization: Learning Process Evidence. Educ. Sci. 2020, 10, 213. [CrossRef]

41. Otemaier, K.R.; Zanese, P.G.; Grein, E.E.; Bosso, N.S. Educational escape room for teaching Mathematical Logic in computer courses. In SBC-Proceedings of the SBGames, Recife, Brazil, 7-10 November 2020; Sociedade Brasileira de Computação: Porto Alegre, Brazil, 2020; pp. 595-604.

42. Elsner, E. How Discourse and Collaboration Can be Used in Mathematics Classrooms to Promote Engagement and Learning Master of Arts in Education; Hamline University: Saint Paul, MN, USA, 2019.

43. Queiruga-Dios, A.; Sánchez, M.J.S.; Dios, M.Q.; Martínez, V.G.; Encinas, A.H. A Virus Infected Your Laptop. Let's Play an Escape Game. Mathematics 2020, 8, 166. [CrossRef]

44. Kirova, G. "The Room of Mysteries" Project for the third Grade. Knowl. Int. J. 2019, 76, 134-139.

45. Tulha, C.N.; De Carvalho, M.A.G.; Coluci, V.R. Educational Digital Game Integrated into a Remote Laboratory for Learning Physic Concepts. In Proceedings of the 2019 IEEE 19th International Conference on Advanced Learning Technologies (ICALT), Maceio, Brazil, 15-18 July 2019; pp. 234-235.

46. Vita Vörös, A.I. Educational Escape Rooms for Physics of Fluids. In Proceedings of the Programme and Book of Abstracts of the GIREP-ICPEEPEC-MPTL Conference 2019, Budapest, Hungary, 1-5 July 2019.

47. Vörös, A.I.V.; Sárközi, Z. Physics escape room as an educational tool. In Proceedings of the Tim17 Physics Conference, Timisoara, Romania, 25-27 May 2017; pp. 050002-1-050002-6. [CrossRef]

48. Woithe, J. Escape Games in Physics Education: Students' Attitudes and Flow Experience. In Proceedings of the GIREP-ICPEEPEC-MPTL 2019 Conference, Budapest, Hungary, 1-5 July 2019.

49. Hou, H.-T.; Chou, Y.-S. Exploring the technology acceptance and flow state of a chamber escape game-Escape the lab@ for learning electromagnet concept. In Proceedings of the 20th International Conference on Computers in Education (ICCE), Singapore, 26-30 November 2012; pp. 38-41.

50. Monnot, M.; Laborie, S.; Hébrard, G.; Dietrich, N. New approaches to adapt escape game activities to large audience in chemical engineering: Numeric supports and students' participation. Educ. Chem. Eng. 2020, 32, 50-58. [CrossRef]

51. Brady, S.C.; Andersen, E.C. An escape-room inspired game for genetics review. J. Biol. Educ. 2019, X, 1-12. [CrossRef]

52. Bartlett, K.A.; Anderson, J.L. Gaming to Learn. In Handbook of Research on Applying Universal Design for Learning Across Disciplines; IGI Global: Derry Township, PA, USA, 2019; pp. 1-27.

53. Healy, K. Using an Escape-Room-Themed Curriculum to Engage and Educate Generation Z Students About Entomology. Am. Entomol. 2019, 65, 24-28. [CrossRef]

54. Mystakidis, S.; Cachafeiro, E.; Hatzilygeroudis, I. Enter the Serious E-scape Room: A Cost-Effective Serious Game Model for Deep and Meaningful E-learning. In Proceedings of the 2019 10th International Conference on Information, Intelligence, Systems and Applications (IISA), Patras, Greece, 15-17 July 2019; pp. 1-6.

55. Hacke, A. Computer Science Problem Solving in the Escape Game Room-X. In Transactions on Petri Nets and Other Models of Concurrency XV; Springer Science and Business Media LLC: Berlin/Heidelberg, Germany, 2019; pp. 281-292. 
56. International Society for Technology in Education (ISTE). Operational Definition of Computational Thinking for K-12 Education. 2011. Available online: http://www.iste.org/docs/pdfs/Operational-Definition-of-Computational-Thinking.pdf (accessed on 11 May 2021).

57. Kahila, J.; Parkki, T.; Gröhn, A.; Karvinen, A.; Telimaa, E.; Riikonen, P.; Tiitta, R.; Haantio, P.; Keinänen, A.; Kerkkänen, T.; et al. Escape Room Game for CT Learning Activities in the Primary School. In Koli Calling '20 Proceedings of the 20th Koli Calling International Conference on Computing Education Research, Koli, Finland, 19-22 November 2020; ACM: New York, NY, USA, 2020; pp. 1-5.

58. Lopez-Pernas, S.; Gordillo, A.; Barra, E.; Quemada, J. Analyzing Learning Effectiveness and Students' Perceptions of an Educational Escape Room in a Programming Course in Higher Education. IEEE Access 2019, 7, 184221-184234. [CrossRef]

59. Veldkamp, A.; Daemen, J.; Teekens, S.; Koelewijn, S.; Knippels, M.P.J.; Van Joolingen, W.R. Escape boxes: Bringing escape room experience into the classroom. Br. J. Educ. Technol. 2020, 51, 1220-1239. [CrossRef]

60. Lin, F.-J.; Wang, C.-P.; Zhung, H.-C.; Wang, H.-Y.; Wang, S.-M.; Li, C.-T.; Li, M.-C.; Hou, H.-T. Paper Romance@—An Educational Simulation Game for Learning Papermaking with Contextual Scaffoldings for Elementary Students: The Evaluation of Learning Performance and Flow State. In Proceedings of the 2017 6th IIAI International Congress on Advanced Applied Informatics (IIAI-AAI), Hamamatsu, Japan, 9-13 July 2017; pp. 1007-1008. [CrossRef]

61. Yllana-Prieto, F.; Jeong, J.S.; González-Gómez, D. An Online-Based Edu-Escape Room: A Comparison Study of a Multidimensional Domain of PSTs with Flipped Sustainability-STEM Contents. Sustainability 2021, 13, 1032. [CrossRef]

62. Pater, E. "Unlock the Future": An Environmental Escape Game and its Development, Evaluation and Impact. Master's Thesis, Uppsala University, Uppsala, Sweden, 2020.

63. Chang, H.-Y.H. Escaping the Gap: Escape Rooms as an Environmental Education Tool. University of California. 2019. Available online: https:/ / nature.berkeley.edu/classes/es196/projects/2019final/ChangH_2019.pdf (accessed on 18 May 2021).

64. Brown, N.; Darby, W.; Coronel, H. An Escape Room as a Simulation Teaching Strategy. Clin. Simul. Nurs. 2019, 30, 1-6. [CrossRef]

65. Martin, L.S.; Walsh, H.; Santerre, M.; Fortkiewicz, J.; Nicholson, L. Creation of a "Patient" Hospital Escape Room Experience to Reduce Harm and Improve Quality of Care. J. Nurs. Care Qual. 2021, 36, 38-42. [CrossRef] [PubMed]

66. McLaughlin, J.L.; Reed, J.A.; Shiveley, J.; Lee, S. Escape Room Blueprint: Central Orientation Contagion Crisis. Simul. Gaming 2021, 52, 24-30. [CrossRef]

67. Frederick, A.N.; Reed, J.A. Operation Outbreak: A Periop 101 Exam Review Escape Room. Simul. Gaming 2021, 52, 88-95. [CrossRef]

68. Wilby, K.J.; Kremer, L.J. Development of a cancer-themed escape room learning activity for undergraduate pharmacy students. Int. J. Pharm. Pract. 2020, 28, 541-543. [CrossRef]

69. Sanders, J.E.; Kutzin, J.; Strother, C.G. Escape the Simulation Room. Simul. Gaming 2021, 52, 62-71. [CrossRef]

70. Phan, M.H.; Keebler, J.; Chaparro, B.S. The Development and Validation of the Game User Experience Satisfaction Scale (GUESS). Hum. Factors J. Hum. Factors Ergon. Soc. 2016, 58, 1217-1247. [CrossRef]

71. Kiili, K. Evaluations of an Experiential Gaming Model. Hum. Technol. 2006, 2, 187-201. [CrossRef]

72. Berthod, F.; Bouchoud, L.; Grossrieder, F.; Falaschi, L.; Senhaji, S.; Bonnabry, P. Learning good manufacturing practices in an escape room: Validation of a new pedagogical tool. J. Oncol. Pharm. Pract. 2019, 26, 853-860. [CrossRef]

73. Morrell, B.; Eukel, H.N. Shocking Escape: A Cardiac Escape Room for Undergraduate Nursing Students. Simul. Gaming 2021, 52, 72-78. [CrossRef]

74. Caldas, L.M.; Eukel, H.N.; Matulewicz, A.T.; Fernández, E.V.; Donohoe, K.L. Applying educational gaming success to a nonsterile compounding escape room. Curr. Pharm. Teach. Learn. 2019, 11, 1049-1054. [CrossRef]

75. Bakker, A. Design Research in Education: A Practical Guide for Early Career Researchers; Routledge: New York, NY, USA, 2018. 